\title{
Evaluating Ecological Footprints through Inbound Tourism, Population Density, and Global Trade
}

\author{
Muhammad Khalid Anser ${ }^{1}$, Zahid Yousaf ${ }^{2}$, Abdelmohsen A. Nassani ${ }^{3}$, \\ Muhammad Moinuddin Qazi Abro ${ }^{3}$, Khalid Zaman**, Ahmad Kabbani ${ }^{5}$ \\ ${ }^{1}$ School of Public Administration, Xi' an University of Architecture and Technology, Xi' an, China \\ ${ }^{2}$ Higher Education Department Khyber Pakhtunkhwa, Government College of Management Sciences, \\ Abbottabad, Pakistan \\ ${ }^{3}$ Department of Management, College of Business Administration, King Saud University, \\ P.O. Box 71115, Riyadh, 11587, Saudi Arabia \\ ${ }^{4}$ Department of Economics, University of Haripur, Khyber Pakhtunkhwa, Haripur, Pakistan \\ ${ }^{5}$ Department of Management, Aleppo University, Aleppo, Syria
}

Received: 7 March 2020

Accepted: 14 May 2020

\begin{abstract}
Environmental damages are largely visible by the man-made actions in general, including an enormous increase in international tourism, huge pressure on arable land by increasing population density, and global international trade. These stated factors are mainly responsible for 'ecological footprints' across the globe. The present study considered these factors in order to evaluate 'ecological footprints' in a panel of 130 countries for a period of 1995-2018. The dynamic differenced GMM estimator is used for empirical illustrations. The study used different regression estimators in order to get robust inferences and found that inbound tourism is the main detrimental factor of global environment that causes 'ecological footprint', which further exhibit the 'inverted U-shaped' relationship between them. Further, population density and countries economic growth first increases and later decreases ecological footprints to support 'inverted U-shaped relationship between them. The Granger causality results unable to verify the 'tourism -led growth' or 'growth -led tourism' hypothesis, while it shows 'no causal' relationship between them, although highly correlated in the regression estimates. Ecological footprint and population density both Granger cause inbound tourism, while the bidirectional relationship found between trade and inbound tourism. Sustainable tourism policies are highly needed to limit ecological footprints across countries.
\end{abstract}

Keywords: ecological footprints, inbound tourism, population density, trade, GMM estimator

*e-mail: khalid_zaman786@yahoo.com 


\section{Introduction}

The subject matter of sustainable tourism is getting high attention in the global environmental agenda to conserve economic and natural resources through eco-friendly tourism, reduced pressure on arable land to develop smart cities planning, and integrated trade cooperation between developed and developing countries for advancement in the cleaner production technologies [1]. These policies could be helpful to reduce 'ecological footprints' in tourism across the globe [2-4]. The present study evaluated four main crucial factors that may cause ecological footprints, including inbound tourism, population density, trade, and economic growth. These stated factors are largely used by the earlier scholars in their writing for evaluating 'ecological footprints' in different economic settings [57]. The study evaluated different plausible hypothesis in this study, including, inbound -induced ecological footprint Kuznets curve (IEF_KC), population -induced ecological footprint Kuznets curve (PEF_KC), growth -induced ecological footprint Kuznets curve (GEF $\mathrm{KC}$ ), and trade -embodied ecological footprint (TEEF). The IEF_KC hypothesis shows that inbound tourism is expected to cause ecological footprints at initial stages of economic development that will be later on decreases to exhibit the 'inverted U-shaped relationship between them [8]. The sustainable tourism policies and economic reforms towards environmental sustainability would be helpful to reduce 'ecological footprints' across countries [9]. The PEF_KC hypothesis assumed that population density will first increase ecological footprints while it will be subsequently decline afterward to substantiate the given hypothesis [10]. The high need of population planning and development of smart cities planning is crucial for reducing ecological footprints across the globe [11]. The GEF_KC hypothesis shows the expected relationship between economic growth and ecological footprints at different stages of growth and assumed that at level, economic growth will increases ecological footprints, which becomes decline at their second degree of coefficient thus it becomes to show non-linear relationship between the two stated factors [12]. The long-term sustainable economic policies and environmental resource management is the optimized solution to conserve natural environment [13]. Finally, The TEEF hypothesis is associated with negative impact of trade on environment to turn out ecological footprints [14]. The tight environmental regulations and emissions -cap trading is considered the sustainable policy instrument to mitigate negative environmental concerns, which caused ecological footprints [15].

The following research questions are important to understand the mechanism through which different economic factors caused by ecological footprints, i.e., does international tourism cause by ecological footprints through increase in the number counts of international tourism arrivals across countries? The inbound tourism is fairly visible to the cause of ecological footprints that need eco-friendly tourism policies all across the globe [16]. Secondly, does increase in per square $\mathrm{km}$ of land area through population density may cause ecological footprints? The high population density is considered another important factor that increases ecological footprints, which can be reduced by proper population planning per square $\mathrm{km}$ of land area [17]. Finally, economic growth and trade openness both assumed to increase ecological footprints, thus the following research question is made for analysis, i.e., does country's economic growth and trade liberalization policies cause ecological footprints? The earlier evidences from scholar writings suggested that both the stated factors negatively affect environment to verify 'pollution haven' hypothesis, which further cause ecological footprints on a global scale [18]. On the basis of research questions, the study made following research objectives, i.e.,

i) to examine the role of inbound tourism in increasing ecological footprints in a panel of selected countries.

ii) to determine the role of population density, economic growth, and trade in ecological footprints, and

iii) to analyze the different alternative and plausible hypotheses related with the candidate variables in causal mechanism and inter-temporal forecast relationship between them.

The study used Arellano-Bond differenced GMM estimator to evaluating the research questions and objectives of the study for robust inferences.

\section{Material and Methods}

The list of the variables that are reported in Table 1 is available for the ready reference. The World Bank [19] database is used to collect the data of the candidate variables of 130 countries for a period of 1995-2018. The study followed the scholarly work of Zaman et al. [20], Ahmed et al. [21], Dogan et al. [22], etc., that identified different environmental factors that cause to ecological footprints in wide economic settings. This study extended the knowledge base by including inbound tourism, population tourism, trade, and economic growth in the relationship of ecological footprints to get more robust inferences. In a given connection, the study developed three different regression equations that empirically analyzed by Arellano-Bond differenced GMM estimates [23], i.e.,

Model-I: Square of Inbound Tourism and Ecological Footprints

$$
\begin{gathered}
\ln (\text { EFPRINT })_{i t}=\alpha_{0}+\alpha_{1} \ln (\text { EFPRINT })_{i t-1} \\
+\alpha_{2} \ln (\text { INBOUND })_{i t}+\alpha_{3} \ln (\text { INBOUND })^{2}{ }_{i t} \\
+\alpha_{4} \ln (\text { PDEN })_{i t} \\
+\alpha_{5} \ln (\text { TOP })_{i t}+\alpha_{6} \ln (\text { GDPpc })_{i t}+z_{i t}+\varepsilon_{i t}
\end{gathered}
$$




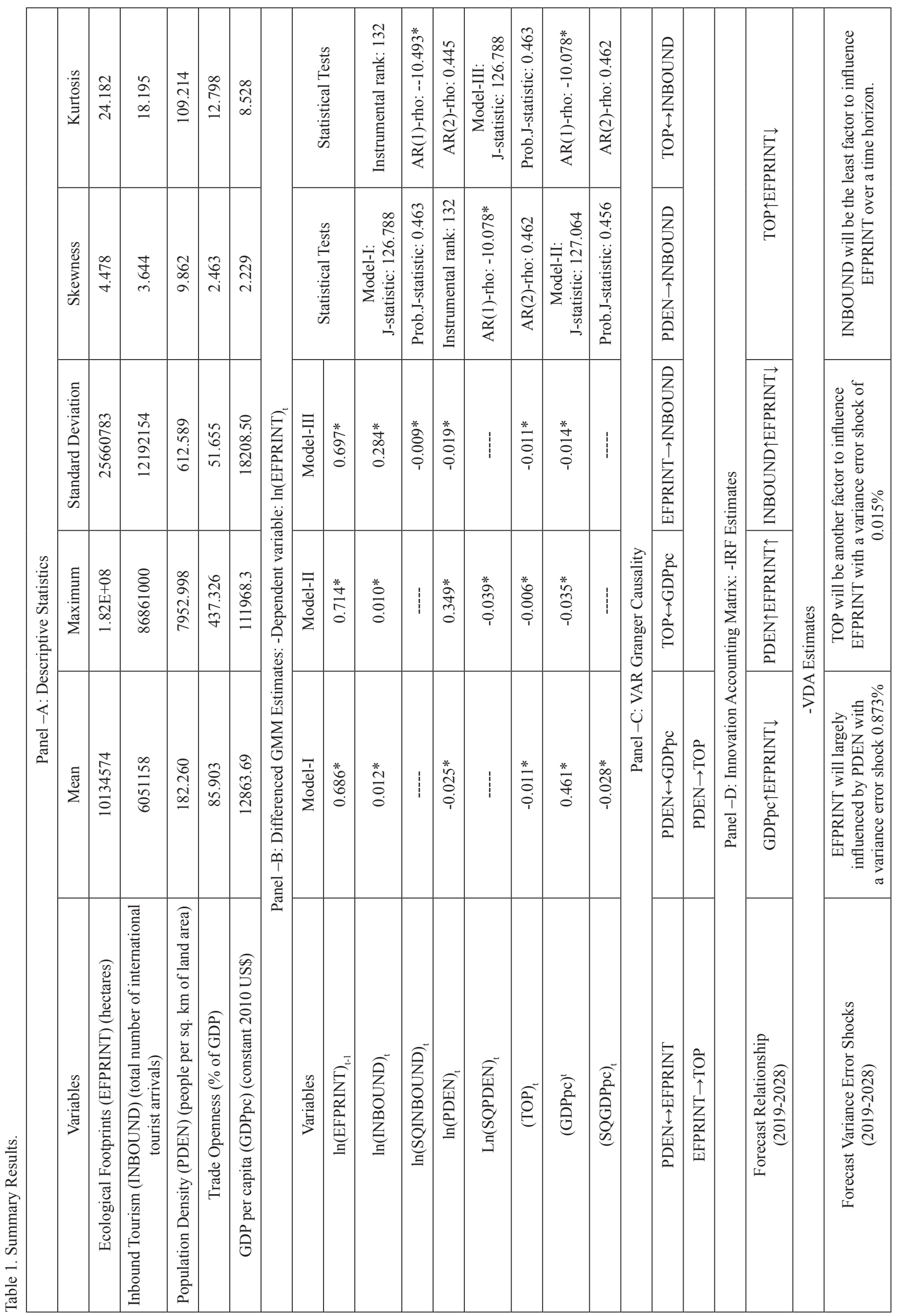


Model-II: Square of Population Density and Ecological Footprints

$$
\begin{aligned}
& \ln (\text { EFPRINT })_{i t}=\beta_{0}+\beta_{1} \ln (\text { EFPRINT })_{i t-1} \\
& +\beta_{2} \ln (\text { INBOUND })_{i t}+\beta_{3} \ln (\text { PDEN })_{i t} \\
& \quad+\beta_{4} \ln (\text { PDEN })_{i t}^{2} \\
& +\beta_{5} \ln (\text { TOP })_{i t}+\beta_{6} \ln (\text { GDPpc })_{i t}+z_{i t}+\varepsilon_{i t}
\end{aligned}
$$

Model-III: Square of Economic Growth and Ecological Footprints

$$
\begin{gathered}
\ln (\text { EFPRINT })_{i t}=\gamma_{0}+\gamma_{1} \ln (\text { EFPRINT })_{i t-1} \\
+\gamma_{2} \ln (\text { INBOUND })_{i t}+\gamma_{3} \ln (\text { PDEN })_{i t} \\
+\gamma_{4} \ln (\text { TOP })_{i t} \\
+\gamma_{5} \ln (\text { GDPpc })_{i t}+\gamma_{6} \ln (\text { GDPPc })_{i t}^{2}+z_{i t}+\varepsilon_{i t}
\end{gathered}
$$

...where, ' $\mathrm{z}$ ' shows instrumental lists, ' $\mathrm{i}$ and $\mathrm{t}$ ' shows cross-section and time period, 'ln' shows natural logarithm, and $\Sigma$ shows error term.

Equations (1) to (3) show the different alternative hypothesis that verified 'IEF_KC' by the expected sign of $\alpha_{2}>0, \alpha_{3}<0$, PEF_KC is verified by the expected sign of $\beta_{3}>0, \beta_{4}<0, \mathrm{GEF}$ KC is verified by the expected sign of $\gamma_{5}>0, \gamma_{6}<0$ and TEEF is prove by the positive relationship between trade and ecological footprints across countries.

\section{Results and Discussion}

Table 1, Panel -A shows that the mean value of ecological footprints is 10134574 hectares with positively skewed distribution and high kurtosis value. Further, the mean value of inbound tourism, population density, trade and economic growth is about 6051158 in numbers, 182.260 people per square $\mathrm{km}$ of land area, $85.903 \%$ of GDP, and US\$12863.69 respectively. The results of Table 1, Panel $-\mathrm{B}$, show that inbound tourism has a positive and significant relationship with ecological footprints in the different regression instruments, which corroborate that the given variable is largely caused to ecological footprints on a global scale. This relationship is not over yet, as inclusion of the second degree polynomial of inbound tourism verifies the 'IEF_KC' hypothesis. The long-term sustainable tourism policies are highly needed to respond ecological footprints across countries [24]. The differential results of population density and ecological footprints found visible in regression of Model-I and Model-III, while the confirmed relationship is found in Model -II by inclusion of square of the said variable and show the inverted U-shaped relationship between the variables to substantiate the PEF_KC hypothesis. The policies to reduce population density by sustainable instruments are highly needed to decrease ecological footprints [25]. The results not verified the 'TEEF hypothesis as trade decreases ecological factors across countries. The sustainable trade policies and rigid environmental reforms both are needed for achieving environmental sustainability on a global scale [26]. Finally, the impact of economic growth on ecological footprints is positive at its initial level that decreases at their succeeding phase to verify the GEF_KC hypothesis. A large number of earlier studies confirmed this causal channel through environmental degradation, thus it is viable to improve natural environment through carbon pricing and cleaner production agenda [27-29].

Table 1, Panel -C, shows the Granger causality estimates and confirmed the bidirectional causality between i) population density and ecological footprints, ii) population density and per capita income, iii) trade openness and economic growth, and trade openness and inbound tourism, while there is a unidirectional causality running from i) ecological footprints to inbound tourism, ii) population density to inbound tourism, iii) ecological footprints to trade openness, and iv) population density to trade openness. The results show the 'no directional causality' between tourism and economic growth, although highly correlated with the ecological footprints. The IRF estimates in Table 1, Panel -D, shows that for the next 10 years time period, there will be the negative error shocks between GDP per capita and ecological footprints, inbound tourism and ecological footprints, and trade openness and ecological footprints, while there will be a positive error shocks between population density and ecological footprints, which indicate that over a time horizon, population density will be the major factor to deteriorate natural environment in the form of ecological footprints across countries. The given results further confirmed with the VDA estimates and found that population density will have a greater magnitude in terms of influencing ecological footprints for the next 10 years time period, followed by trade openness with a magnitude of $0.015 \%$. The least contributor will be inbound tourism that will cause of ecological footprints across countries.

\section{Conclusions}

The United Nation sustainable development goals always provoked the need of environmental sustainable policies in order to combat climate change by limiting GHG emissions. The man -made actions build an enormous pressure on natural environment in the form of ecological footprints that could be reduced by sustainable tourism policies, residential population planning, and integrated eco-friendly goods trade. This study worked in the similar lines to evaluate ecological footprints through inbound tourism, population density, and trade by using the large panel of selected countries for a period of 1995-2018. The ArellanoBond differenced GMM estimates confirmed the wide 
plausible hypotheses, which is imperative for devising long-term sustainable development policies. The results show that inbound tourism, population density, and economic growth exhibit the non-linear relationship with the ecological footprints and exhibit the inverted U-shaped relationship between them. The Granger causality estimates confirmed the feedback relationship of i) population density with ecological footprints and GDP per capita, and ii) trade openness with GDP per capita and inbound tourism while the one-way causal relationship found from ecological footprint to inbound tourism, population density to inbound tourism, ecological footprint to trade, and population density to trade. The forecast relationship shows that country's economic growth, inbound tourism, and trade will negatively influence ecological footprints while population density will be positively influenced ecological footprints with a greater variance error shock of $0.873 \%$. The following sustainable policies are desirable for achieving long-term sustainable development across countries, i.e.,

i) The clean environmental awareness programmes should be initiated for the international tourists to provide complete guidance and counseling to ensure safe and healthy visitation for keeping the tourism spots green and clean.

ii) The smart residential area and proper population planning could be the need of the time to respond to the international call of achieving environmental sustainability to reduce population density, which is the detrimental factor of increasing global ecological footprints.

iii) The advancement in the technological up gradation and technological goods exports are highly needed between the developed and developing countries, thus mutual cooperation among the countries and sustainable integrated trade policies could reduce the cumbersome of ecological footprints across countries, and.

iv) The sustainable economic and tourism policies are largely needed in order to limit high carbon abatement cost for reducing ecological footprints across the globe.

These environmental policies could be helpful to restore natural scenic tourists' spots and increase safe and health visitation, which could be further translated in to long-term sustainable growth on a global scale.

\section{Acknowledgements}

Researchers Supporting Project number (RSP2020/87), King Saud University, Riyadh, Saudi Arabia.

\section{Conflict of Interest}

The authors declare no conflict of interest.

\section{References}

1. ANSER M.K., YOUSAF Z., AWAN U., NASSANI A.A., ABRO M.M.Q., ZAMAN K. Identifying the Carbon Emissions Damage to International Tourism: Turn a Blind Eye. Sustainability, 12(5), 1937, 2020.

2. SÖRENSSON A., VON FRIEDRICHS Y. An importanceperformance analysis of sustainable tourism: A comparison between international and national tourists. Journal of Destination Marketing \& Management, 2(1), 14, 2013.

3. KVASOVA O. The Big Five personality traits as antecedents of eco-friendly tourist behavior.Personality and Individual Differences,83, 111, 2015.

4. KATIRCIOGLU S., GOKMENOGLU K.K., EREN B.M. Testing the role of tourism development in ecological footprint quality: evidence from top 10 tourist destinations. Environmental Science and Pollution Research, 25 (33), 33611, 2018.

5. OZTURK I., AL-MULALI U., SABOORI B. Investigating the environmental Kuznets curve hypothesis: the role of tourism and ecological footprint. Environmental Science and Pollution Research, 23 (2), 1916, 2016.

6. RUDOLPH A., FIGGE L. Determinants of Ecological Footprints: What is the role of globalization?. Ecological Indicators, 81, 348,2017.

7. TIAN G., HUANG J. Comparative Advantages of China's Foreign Trade from the Perspective of Ecological Footprint. Ekoloji, 27 (106), 1687, 2018.

8. QURESHI M.I., ELASHKAR E.E., SHOUKRY A.M., AAMIR A., MAHMOOD N.H.N., RASLI A.M., ZAMAN $\mathrm{K}$. Measuring the ecological footprint of inbound and outbound tourists: evidence from a panel of 35 countries. Clean Technologies and Environmental Policy, 21(10), 1949, 2019

9. YE Q., ANWAR M.A., ZHOU R., ASMI F., AHMAD I. Short stay, long impact: ecological footprints of sojourners. Environmental Science and Pollution Research, 1-12, 2020.

10. MUÑIZ I., GARCIA-LÓPEZ M.À. Urban form and spatial structure as determinants of the ecological footprint of commuting. Transportation Research Part D: Transport and Environment, 67, 334, 2019.

11. BRADSHAW C.J., DI MININ E. Socio-economic predictors of environmental performance among African nations. Scientific reports, 9 (1), 1, 2019.

12. HASSAN S.T., XIA E., KHAN N.H., SHAH S.M.A. Economic growth, natural resources, and ecological footprints: evidence from Pakistan. Environmental Science and Pollution Research, 26 (3), 2929, 2019.

13. SHAHEEN K., ZAMAN K., BATOOL R., KHURSHID M.A., AAMIR A., SHOUKRY A.M., SHARKAWY M.A., ALDEEK F., KHADER J., GANI S. Dynamic linkages between tourism, energy, environment, and economic growth: evidence from top 10 tourism-induced countries. Environmental Science and Pollution Research, 26 (30), 31273, 2019.

14. KOLCAVA D., NGUYEN Q., BERNAUER T. Does trade liberalization lead to environmental burden shifting in the global economy?. Ecological Economics, 163, 98, 2019.

15. ANSER M.K., YOUSAF Z., USMAN B., NASSANI A.A., ABRO M.M.Q., ZAMAN K. Management of water, energy, and food resources: Go for green policies. Journal of Cleaner Production, 251, 119662, 2020.

16. KHAN A., BIBI S., ARDITO L., LYU J., HAYAT H., ARIF A.M. Revisiting the Dynamics of Tourism, 
Economic Growth, and Environmental Pollutants in the Emerging Economies - Sustainable Tourism Policy Implications. Sustainability, 12 (6), 2533, 2020.

17. AHMED Z., ZAFAR M.W., ALI S. Linking urbanization, human capital, and the ecological footprint in G7 countries: An empirical analysis. Sustainable Cities and Society, 55, 102064, 2020.

18. KHAN A., CHENGGANG Y., XUE YI W., HUSSAIN J., SICEN L., BANO S. Examining the pollution haven, and environmental kuznets hypothesis for ecological footprints: an econometric analysis of China, India, and Pakistan. Journal of the Asia Pacific Economy, https://doi. org/10.1080/13547860.2020.1761739, 2020.

19. WORLD BANK. World Development Indicator, World Bank, Washington D.C, 2019.

20. ZAMAN K., SHAHBAZ M., LOGANATHAN N., RAZA S.A. Tourism development, energy consumption and Environmental Kuznets Curve: Trivariate analysis in the panel of developed and developing countries. Tourism Management, 54, 275, 2016.

21. AHMED K., OZTURK I., GHUMRO I.A., MUKESH P. Effect of trade on ecological quality: a case of D-8 countries. Environmental Science and Pollution Research, 26 (35), 35935-35944, 2019.

22. DOGAN E., TASPINAR N., GOKMENOGLU K.K. Determinants of ecological footprint in MINT countries. Energy \& Environment, 30 (6), 1065, 2019.

23. ARELLANO M., BOND S. Some tests of specification for panel data: Monte Carlo evidence and an application to employment equations. The review of economic studies, 58 (2), 277, 1991.

24. DONG H., LI P., FENG Z., YANG Y., YOU Z., LI Q. Natural capital utilization on an international tourism island based on a three-dimensional ecological footprint model: A case study of Hainan Province, China. Ecological Indicators, 104, 479, 2019.

25. YUE S., MUNIR I.U., HYDER S., NASSANI A.A., ABRO M.M.Q., ZAMAN K. Sustainable food production, forest biodiversity and mineral pricing: Interconnected global issues. Resources Policy, 65, 101583, 2020.

26. ALOLA A.A. The trilemma of trade, monetary and immigration policies in the United States: Accounting for environmental sustainability. Science of The Total Environment, 658, 260, 2019.

27. HASHMI R., ALAM K. Dynamic relationship among environmental regulation, innovation, $\mathrm{CO}_{2}$ emissions, population, and economic growth in OECD countries: A panel investigation. Journal of cleaner production, 231, 1100, 2019.

28. XIONG Z., LI H. Ecological deficit tax: A tax design and simulation of compensation for ecosystem service value based on ecological footprint in China. Journal of Cleaner Production, 230, 1128, 2019.

29. DANISH HASSAN S.T., BALOCH M.A., MAHMOOD N., ZHANG J. Linking economic growth and ecological footprint through human capital and biocapacity. Sustainable Cities and Society, 47, 101516, 2019. 